Published by Al-Nahrain College of Medicine P-ISSN 1681-6579

E-ISSN 2224-4719

Email: iraqijms@colmed-alnahrain.edu.iq

http://www.colmed-alnahrain.edu.iq

http://www.iraqijms.net

Iraqi JMS 2018; Vol. 16(3)

\title{
Adenovirus Infection in a Sample of Iraqi Kidney Transplant Recipients: Molecular and Hematological Study
}

\author{
Hind M. Ahmed MSC, Asmaa B. Al-Obaidi ${ }^{1}$ PhD, Mustafa R. Hussein ${ }^{2}$ FICMS, Haider S. Kadhim ${ }^{1}$ \\ $P h D$, Haider F. Ghazi ${ }^{1} P h D$
}

${ }^{1}$ Dept. of Medical Microbiology, College of Medicine, Al-Nahrain University, Baghdad, Iraq, ${ }^{2}$ Center of Kidney Diseases and Transplantation, Medical City of Baghdad, Iraq

\begin{abstract}
Background Human Adenovirus (ADV) is one of highly prevalent viruses worldwide, after primary infection, it remains latent and then might reactivate in immunocompromised patients. High ADV viremia seen in renal transplant recipients (RTR) with clinical presentations range from asymptomatic viremia to respiratory and gastrointestinal disease hemorrhagic cystitis, graft dysfunction and severe disseminated disease.

Objective The objectives of this study are to determine the rate of occurrence of ADV viremia by quantitative Real time PCR (QRT-PCR) in RTR and correlate them with urine cytology results, renal function tests and patients' hematological parameters.

Methods Seventy-one renal transplant recipients (RTR) were enrolled in this study. Whole blood samples (3 ml) divided into two parts, one part for complete blood picture and differential count and other part from which plasma separated and subjected to viral DNA extraction and then ADV Taqman QRT-PCR analysis for viral load measurement. Five $\mathrm{ml}$ urine specimens were collected for Pap-stained urine cytology.

Results Out of 71 RTR, $15(21.12 \%)$ had positive ADV viremia by QRT-PCR, with a mean viral load $4.0 \times 10^{7} \pm 1.9$ $\mathrm{x} 10^{8}$ copies $/ \mathrm{ml}$, and $80 \%$ (12 out of the 15 ) of positive viremia patients aged more than 40 years $(p=0.011)$. All of RTRs $15 / 15(100 \%)$ had symptomatic urinary tract infection (UTI) $(p=0.039)$, and 5 out of 9 patients who had lymphopenia had positive viremia $(p=0.007)$. Pap-stained urine cytology smears showed that $39 / 71$ (55.71\%) of the RTRs had positive decoy cells (DC), but there was no significant correlation between ADV viremia and the presence of $D C(p=0.107)$.

Conclusion The present study showed the prevalence of ADV viremia in RTRs, with very high viral load, which is associated with lymphopenia and overt clinical features, this suggests that ADV might be an important cause of morbidity in RTRs.

Keywords

Citation

Adenovirus, renal transplantation, real-time PCR, urine cytology

Ahmed HM, Al-Obaidi AB, Hussein MR, Kadhim HS, Ghazi HF. Adenovirus infection in a sample of iraqi kidney transplant recipients: molecular and hematological study. Iraqi JMS. 2018; 16(3): 279-288. doi: 10.22578/IJMS.16.3.7
\end{abstract}

List of abbreviations: $A D V=$ Adenoviruses, $\mathrm{CYC}=$ Cyclosporine, $\mathrm{DC}=$ decoy cells, $\mathrm{IS}=$ Immunosuppressive drugs, $\mathrm{MMF}=$ Mycophenolate, QRT-PCR = Quantitative real time polymerase chain reaction, $\mathrm{RTR}=$ Renal transplant recipients, $\mathrm{TAC}=$ Tacrolimus, UTI = urinary tract infection

\section{Introduction}

Cince first isolation from adenoid tissue over 60 years ago, human adenoviruses $\circlearrowleft$ (ADV) belonging to Adenoviridae family, and the Mast adenovirus genus that have made continuous challenges in different clinical manifestations. Adenoviruses are divided into seven species, from $A$ through $G^{(1-3)}$. It has been reported more than 67 ADV types according to the gene bank for human adenovirus genotype classification (4). Human ADVs known to cause a number of clinical manifestations, including keratoconjunctivitis, gastroenteritis, hemorrhagic cystitis, and 
common cause of upper and lower respiratory tract infections, that produce in vitro cytolysis in these tissues ${ }^{(5)}$.

Adenoviruses play an important role in patients with impaired immune responses, in whom viral diseases cause high morbidity and mortality. In the solid organ transplant recipients (SOT), the primary site of ADV disease is mainly related to the transplanted organ. Some of the clinical presentations occur in lung, liver, renal, and small bowel transplantations including pneumonia, hepatitis, nephritis, hemorrhagic cystitis, enteritis, and less commonly disseminated disease ${ }^{(6)}$.

In renal transplant recipients (RTRs), the most common presentation is acute hemorrhagic cystitis and, to a lesser extent, pneumonia, with a $17 \%$ fatality rate ${ }^{(7)}$. Adenoviruses are included in the pathogens responsible for infections in the immediate posttransplantation period (PTP) as either primary infection or reactivation of a previous infection ${ }^{(8)}$, in less than $2 \%$ of ADV cases, which presents as pneumonitis, nephritis, diarrhea, and hemorrhagic colitis or cystitis, the infection can become generalized and cause multiple organ failure ${ }^{(9,10)}$.

Adenovirus infection was shown earlier after kidney transplantation, correlated with low absolute lymphocyte counts, and such patients develop more severe complications and progressive disease, in whom lymphocyte count can be used as a predictor of adenovirus disease and patient outcome ${ }^{(11)}$. In addition, ADV infection in kidney transplantation could be predicted when there is decoy cells (DC) in Pap-stained urine cytology but less commonly than polyomaviruses ${ }^{(12-14)}$.

Progress in molecular detection methods especially quantitative real time PCR (QRT-PCR) has made the detection and monitoring of adenovirus diseases easily applicable in the clinical practice, in addition real time PCR is available for assessment of risk and accurate rapid diagnosis of invasive ADV infection (15).
In Iraq, several studies had been conducted on viral infections in RTRs, including human cytomegalovirus, BK and JC polyomaviruses, Epstein Barr virus, Human Herpes virus- 6 and Parvovirus B19 (16-22). However, to the best of our knowledge, this study is the first to investigate the prevalence of ADV viremia in Iraqi RTRs using QRT-PCR.

The objectives of the present study are detection of ADV viremia in kidneytransplanted patients by QRT-PCR, Screening of Pap-stained urine cytology smears for viral inclusions, correlate ADV viremia with patients' clinical presentation and renal function tests, and study the relation between the level of ADV viremia and patients' hematological parameters.

\section{Methods}

\section{Study Population and Sampling}

Cross sectional study conducted from November 2016 to April 2017, seventy-one RTRs were collected from the (Center of Kidney Diseases and Transplantation) in the Medical City of Baghdad. A consent letter obtained from all patients enrolled in the study. This study approved by the ethical committee of the College of Medicine-Al-Nahrain University. The study was conducted in the Microbiology Department at the College of Medicine-AlNahrain University.

Clinical parameters (immunosuppressive regimens, acute rejection episodes, transplant renal function, any signs and symptoms, and late complications) obtained from patient's medical records. Two main Standard immunosuppressive regimens were mainly followed in RTRs; either the cyclosporine (CYC), mycophenolate (MMF), and prednisolone, or the regimen that included tacrolimus (TAC) instead of CYC, in addition to MMF and prednisolone. And induction with monoclonal anti-CD25 antibodies (Basilixibam/Daclizumab) From all 71 RTRs, three $\mathrm{ml}$ blood samples collected and divided in to two parts, one part for complete blood picture and differential lymphocytes count, and other part from which 
plasma separated and subjected to viral DNA extraction and then ADV Taqman quantitative Real time PCR analysis for viral load measurement. Five $\mathrm{ml}$ urine specimens collected and preserved in 95\% ethanol 1:1 for Pap-stained urine cytology smear.

\section{Viral DNA Extraction}

For viral DNA extraction from the blood samples; Geneius ${ }^{\mathrm{TM}}$ Viral Nucleic Acid Extraction Kit III (Geneaid, England) was used. One $\mathrm{ml}$ plasma sample used in viral DNA extraction, according to the manufacturer protocol.

\section{Real Time PCR for Measuring ADV Viremia}

For the quantitative detection of $A D V$; Adenovirus [R-gene ${ }^{\circledR}$ Ref.:69-010B France] is a Real-Time test, which is based on the principle of the so-called- "TaqMan" probe. Fifteen $\mu$ of Master Mix added into PCR tubes, and $10 \mu \mathrm{l}$ of the (sample DNA, sensitivity controls, or standards) were added to the master mix. The final reaction volume was $25 \mu$ l. All components were kept at $+2{ }^{\circ} \mathrm{C}$ to $+8{ }^{\circ} \mathrm{C}$ during the PCR preparation. Real time PCR instrument used in this work was7500 Real Time PCR System Applied biosystems (USA). The thermal protocol for Adenovirus R-gene ${ }^{\circledR}$ PCR kit is composed of a two hold steps, a one amplification cycle. The real-time data is collected at the third step of the amplification cycle. The size of the amplified fragment is 138 bp and is located in the Hexon gene coding for hexagonal capsomeres which form the subunits of the adenovirus capsid protein. An Internal Standard (IC2) is included in the reaction mix controlling the possible inhibition of the PCR reaction. IC2 positive amplification is detected in the HEX fluorophore fluorescence channel. A range of 4 quantification standards is provided with the ADENOVIRUS Rgene ${ }^{\circledR}$ kit ranged from 5000 copies/ $\mu$ lo 5 copies/ $\mu l$. These quantification standards used to generate a new standard curve in the software provided with the thermocycler. The quantification of Adenovirus genome in unknown samples is extrapolated from this standard curve. At the end of the thermal protocol, the 7500 Real Time PCR System Applied biosystems instrument software automatically calculates the baseline cycles and the threshold. The standard curve is plotted using the data obtained from the defined standards, with the $(\mathrm{Y})$ axis is the CtThreshold Cycle, and the $(X)$ axis is the viral DNA copy number. According to the manufacturer instructions, ADV DNA copies was calculated according to the following formula (23):

$$
\operatorname{copy} / \mathrm{ml}=\frac{\mathrm{SC} \times \mathrm{EV}}{\mathrm{IV}}
$$

$\mathrm{SC}=$ Sample Concentration (copy/ $\mu \mathrm{L})$

$\mathrm{EV}=$ Elution Volume $(\mu \mathrm{l})$

IV = Isolation Volume (ml)

\section{Results}

Among these 71 RTR; 49 (69.01\%) were males, and 22 (30.98\%) were females; their mean age was $37.06 \pm 12.73$ years, ranging between 18 and 63 years, and the mean PostTransplantation Period (PTP) was $10.44 \pm 5.54$ months. The mean body weight of the RTRs was $75.54 \pm 8.5 \mathrm{Kg}$, while their mean serum creatinine value was $1.16 \pm 0.28$, and the mean of their creatinine clearance was $92.08 \pm 20.58$, and among all the RTRs; 9/71 (12.6\%) had lymphopenia. All the RTRs received their allografts from living donors, and out of the 71 RTRs; 32 (45.07\%) received their allograft kidney from living related donors, while the remaining 39 (54.93\%) received their kidney allograft from living unrelated donors. Regarding the type of immunosuppression, $37 / 71$ (52.11\%) were on (CYC) and the reminder $34 / 71$ (47.88\%) were on (TAC) regimen.

Depending on the patient's files and questioner at the time of collection, the majority RTRs enrolled in this study had clinical presentations 
and complications at the time of sampling, symptomatic urinary tract infections (UTI) were the highest among these presentations as shown in the table (1). Out of the 71 RTRs 40 (56.33\%) were hypertensive and 10 (14.08\%) were diabetic

Table 1. Clinical presentations of RTRs at the time of sampling

\begin{tabular}{cc}
\hline Clinical presentation & No. (\%) out of 71 RTRs \\
\hline UTI & $58(81.69 \%)$ \\
Respiratory disease & $39(54.92 \%)$ \\
Gastroenteritis & $36(50.70 \%)$ \\
Hematuria & $23(32.39 \%)$ \\
Eye infection & $15(21.12 \%)$ \\
\hline
\end{tabular}

Urine cytology smears were Papanicolaoustained and microscopic examination showed that $39 / 71$ (55.71\%) of the RTRs had positive Decoy cells. Figure (1) shows various types of decoy cells among RTRs.

QRT-PCR for detection and quantitation of ADV (a hexon gene which is common to all adenoviral species) in plasma sample (viremia), was positive in 15 out of 71 (21.12\%) RTRs. The mean of ADV Viremia was $4.0 \times 10^{7} \pm 1.9 \times 10^{8}$ copies $/ \mathrm{ml}$. The standard curve of QRT-PCR included the four quantification standards ranged from 5000 copies/ $\mu$ lo 5 copies/ $\mu$ l. Statistical data in table (2) demonstrated that $80 \%$ (12 out of the 15) patients who had positive viremia aged more than 40 years which is statistically significant $(p=0.011)$. There is no significant difference in gender, nevertheless, 9 out of 15 (60\%) positive ADV viremia patients were males, while females were 6 out of 15 (40\%) ADV positive cases $(p=0.395)$.This study found no significant association between positive viremia and gender type, transplantation period, serum creatinine, creatinine clearance test, and the type of immunosuppression. Regarding the association between ADV viremia and clinical presentations all of RTRs 15/15 (100\%) who had positive ADV viremia; had symptomatic UTI, which was statistically significant $(p=0.039)$. Although there were no significant association between ADV viremia and other clinical presentations, however, about 30\%, $25 \%$ and $23 \%$ of those patients who had hematuria, gastroenteritis, and respiratory infections had positive adenovirus viremia, respectively. Pap-stained urine cytology results showed no significant correlation between ADV viremia and the presence of decoy cells (DC), but $73.3 \%$ (11 out of 15 positive viremia cases) had positive DCs in urine. On the other hand, (55.6\%) 5 out of 9 patients who had lymphopenia (lymphocytes count in the blood below 1.0X109) had positive ADV in plasma, which was statistically significant $(p=0.007)$. In addition, there was a significant association between the value of viral load and lymphopenia in RTRs ( $p=0.023)$. 

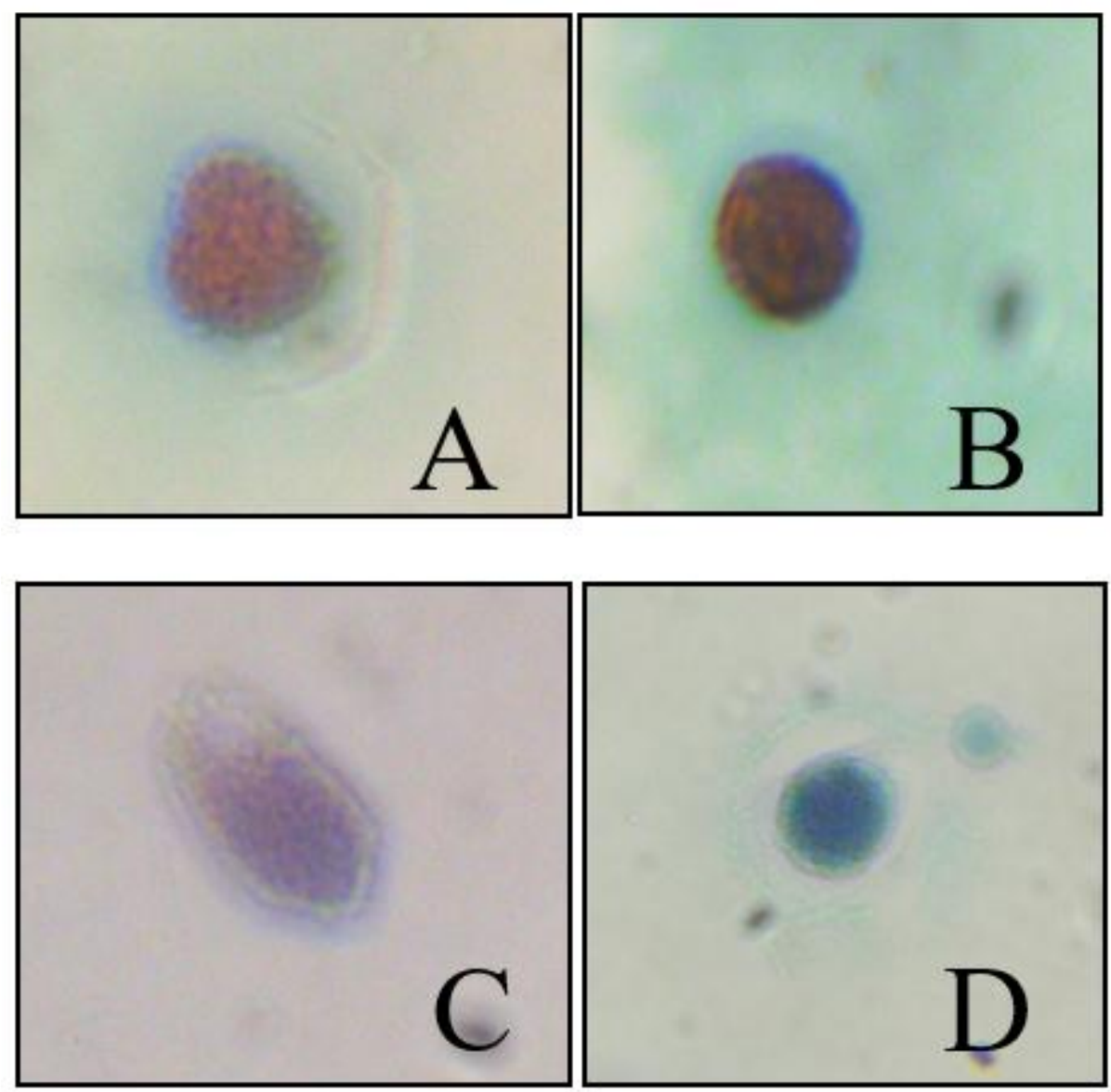

Figure 1. Pap-stained urine cytology smears demonstrate: ( $A$ and $B$ ) Common ground glass virusinfected (decoy cells (DC)). (C) Common comet-shaped DC. (D) Uncommon clumped variant DC. Magnification power for A (100X), B, C, D (40X)

\section{Discussion}

In this study, ADV was investigated in the plasma sample of RTRs using QRT-PCR, and the results showed that more than one-fifth of the RTRs (15 out of 71 (21.12\%) had positive ADV viremia in plasma, this frequency is in the range of other studies, that spam between 5 to $22 \%(24,25)$. These results were significantly correlated with RTRs who had low lymphocytes count (lymphopenia). ADV infection in RTRs may be a consequence of a primary infection, reactivation of latent infection or acquired through donor organs, and it is believed that majority of the cases are due to reactivation of latent infection (26). The mean of ADV viremia was $4.0 \times 10^{7} \pm 1.9 \times 10^{8}$ copies $/ \mathrm{ml}$, which is a very high viral load associated with wide range of clinical manifestations, in which $30 \%, 25 \%$ and $23 \%$ of those patients who had hematuria, gastroenteritis, and respiratory infections had positive ADV viremia, respectively. These results are in line with other previous studies on ADV infection in RTRs that showed high mean viral load in immunocompromised patients (27-29). In immunocompromised patients, the immune escape and persistence of ADV mediated by different mechanisms. Specific viral proteins can block responses to anti-inflammatory and cytolytic cytokines, intrinsic cellular apoptosis, and innate and adaptive cellular immune responses (30). Moreover, the viral protein E3 can down regulate major histocompatibility complex (MHC) class I molecules, there by affecting antigen presentation and reducing T-cell attack of the infected cells ${ }^{(31,32)}$. 
Table 2. Comparisons of the patients with positive ADV viremia and negative viremia including transplants' demographic, clinical and laboratory data

\begin{tabular}{|c|c|c|c|c|c|}
\hline & & Positive ADV & Negative ADV & Total & $p$ value \\
\hline \multirow{2}{*}{ Age } & $<40$ years & $3(8.6)$ & $32(91.4)$ & 35 & \multirow{2}{*}{0.011} \\
\hline & $\geq 40$ years & $12(33.3)$ & $24(66.7)$ & 36 & \\
\hline \multirow{2}{*}{ Gender } & Male & $9(18.4)$ & $40(81.6)$ & 49 & \multirow{2}{*}{0.395} \\
\hline & Female & $6(27.3)$ & $16(72.7)$ & 22 & \\
\hline \multirow{2}{*}{ PTP } & $\leq 1$ year & $9(19.1)$ & 38 (80.9) & 47 & \multirow{2}{*}{0.568} \\
\hline & $>1$ year & $6(25.0)$ & $18(75.0)$ & 24 & \\
\hline \multirow{2}{*}{ Relatedness } & Related & 7 (21.9) & $25(78.1)$ & 32 & \multirow{2}{*}{0.980} \\
\hline & Unrelated & $8(21.6)$ & $29(78.4)$ & 37 & \\
\hline \multirow{2}{*}{ IS Drugs } & CYC & $9(24.3)$ & $28(75.7)$ & 37 & \multirow{2}{*}{0.491} \\
\hline & TAC & $6(17.6)$ & $28(82.4)$ & 34 & \\
\hline \multirow{2}{*}{ Rejection } & No & $15(22.1)$ & $53(77.9)$ & 68 & \multirow{2}{*}{0.360} \\
\hline & Yes & $0(0.0)$ & $3(100)$ & 3 & \\
\hline \multirow{2}{*}{$\begin{array}{c}\text { Frequency of } \\
\text { transplantation }\end{array}$} & Once & $15(22.1)$ & $53(77.9)$ & 68 & \multirow{2}{*}{0.360} \\
\hline & Twice & $0(0.0)$ & $3(100)$ & 3 & \\
\hline \multirow{2}{*}{ Respiratory Infection } & Yes & $9(23.1)$ & 30 (76.9) & 39 & \multirow{2}{*}{0.657} \\
\hline & No & $6(18.8)$ & $26(81.3)$ & 32 & \\
\hline \multirow{2}{*}{ Gastroenteritis } & Yes & $9(25.0)$ & $27(75)$ & 36 & \multirow{2}{*}{0.417} \\
\hline & No & $6(17.1)$ & $29(82.9)$ & 35 & \\
\hline \multirow{2}{*}{ Eye Infection } & Yes & $1(6.7)$ & 14 (93.3) & 15 & \multirow{2}{*}{0.122} \\
\hline & No & $14(25.0)$ & $42(75)$ & 56 & \\
\hline \multirow{2}{*}{ UTI } & Yes & $15(25.9)$ & $43(74.1)$ & 58 & \multirow{2}{*}{0.039} \\
\hline & No & $0(0.0)$ & $13(100)$ & 13 & \\
\hline \multirow{2}{*}{ Hematuria } & Yes & $7(30.4)$ & $16(69.6)$ & 23 & \multirow{2}{*}{0.184} \\
\hline & No & $8(16.7)$ & $40(83.3)$ & 48 & \\
\hline \multirow{2}{*}{ Hypertension } & Yes & $9(22.5)$ & $31(77.5)$ & 40 & \multirow{2}{*}{0.747} \\
\hline & No & $6(19.4)$ & $25(80.6)$ & 31 & \\
\hline \multirow{2}{*}{ Diabetes } & Yes & $3(30.0)$ & $7(70.0)$ & 10 & \multirow{2}{*}{0.458} \\
\hline & No & $12(19.7)$ & $49(80.3)$ & 61 & \\
\hline & Yes & $11(28.2)$ & $28(71.8)$ & 39 & 107 \\
\hline Urine cytology & No & $4(12.5)$ & $28(87.5)$ & 32 & $0.10 /$ \\
\hline & Yes & $5(55.6)$ & $4(44.4)$ & 9 & \\
\hline Lymphopenia & No & $10(16.1)$ & $52(83.9)$ & 62 & 0.007 \\
\hline & Abnormal & $4(20.0)$ & $16(80.0)$ & 20 & \\
\hline Creatınıne Clearance & Normal & $11(21.6)$ & $40(78.4)$ & 51 & 0.884 \\
\hline Serum Creatinine & Normal & $9(19.1)$ & $38(80.9)$ & 47 & 0568 \\
\hline serum Creatınıne & Abnormal & $6(25.0)$ & $18(75.0)$ & 24 & 0.568 \\
\hline
\end{tabular}

PTP: Post-transplantation period, IS: Immunosuppressive, CYC: Cyclosporine, TAC: Tacrolimus, UTI: Urinary tract infection

In addition, studies found this high viral load is associated with many manifestations like pyelonephritis ${ }^{(33,34)}$, hemorrhagic cystitis $(35,36)$, respiratory infections ${ }^{(37-39)}$, and GIT infections
(40-42). However, it should be noted that the high number of patients with upper and lower respiratory tract infections could be mainly because the time of collecting the patients in 
this study, which was mainly during the winter season (November to April).

The present study found that $7 / 15$ (46.6\%) of RTRs who had positive ADV viremia had hematuria as clinical symptom during collecting the sample this is supported by Hofland et al. 2004, (43) who reviewed 37 cases of ADV hemorrhagic cystitis in kidney transplant recipients, and showed that in RTRs, the most common manifestation is hemorrhagic cystitis. Also, the current study had significant association between ADV viremia and UTI that could be supported by other studies, which found a correlation between adenovirus infection and cystitis and pyelonephritis, with white cell casts in urine ${ }^{(34,44)}$. Kolankiewicz et al. in $2010{ }^{(34)}$ published a case report and a review of the literature in which the patients commonly presented with gross hematuria and dysuria (10/11), fever (9/11), and acute renal failure (9/11), and $27 \%$ of the patients had significant graft function impairment after adenoviral nephritis. Rady et al. in 2014 (44) described a case of necrotizing tubulointerstitial allograft nephritis due to adenovirus infection, a significant proportion of patients presented within 8 months of transplant with gross hematuria, dysuria, fever and acute renal failure.

Although there was no statistically significant association of ADV viremia with respiratory infection, nevertheless, 9 out of 15 ADV positive patients had respiratory disease, which was also showed in other studies Watanabe et al. in 2013, in which all patients enrolled in the study had acute respiratory tract infections (37). Respiratory tract disease ranged from mild upper-tract involvement (URI), typically presenting nonspecific cold like symptoms, to severe pneumonia (39) which agrees with the patients' presentations in this study. In addition, this study found that 9 out of 15 ADV positive patients had gastrointestinal symptoms, mostly diarrhea, although there was no statistically significant association between ADV viremia and GIT disease, another study also showed that GIT infection occurred in RTRs, symptoms ranged from mild diarrhea to hemorrhagic colitis ${ }^{(32)}$.
Results of the current study found a statistically significant association between ADV viremia and low lymphocytes count (lymphopenia) 5 out of $15(33.3 \%)(p=0.007)$ which is supported by the study of Watcharananan et al. in 2011 who showed that early ADV infection appeared to have significantly lower lymphocytes count at several time points compared to those with late infection (11). This finding underscores the influence of immune recovery during the course of infection ( ${ }^{45,46)}$. Heemskerk et al. in 2005 found exogenous lymphocyte therapy in the form of donor lymphocyte infusions has been successful in some cases (46). Cohort of retrospective study of Kim et al. in 2015, found that a low absolute lymphocyte count within 3 months in allogeneic transplantation recipients was significantly associated with poor overall survival, progression-free survival, and mortality (47). Ison in $2006^{(5)}$ demonstrated an association between lymphocyte recovery and recovery from adenoviral infections in RTRs.

On the other hand, there was no significant association between ADV infection and the level of serum creatinine and creatinine clearance $(\mathrm{CrCl})$, a result might exclude the possibility of an associated renal impairment with adenoviremia, and this result is supported by other studies in RTRs that excluded the role of ADV in renal impairment or rejection (48). Nanmoku et al. in $2016^{(49)}$ also showed there is no significant difference was seen before, during, or after disease onset of ADV infection. However, most of the studies reported sporadic cases of renal allograft impairment associated with ADV viremia $(13,44,50)$.

Although the results of present study showed no significant association between ADV viremia and urine cytology findings, however, $(73,3 \%)$ 11 out of these 15 ADV positive cases had positive decoy cells in Pap-stained urine cytology smears. A result can support the high association of ADV viremia with different urinary, gastrointestinal and respiratory complaints in these RTRs. Studies showed that although it is rare, but adenovirus is one of the viruses that are associated with urinary decoy cells shedding ${ }^{(5)}$. Viral cytopathic changes (decoy cells), which are typically associated with polyomavirus infection, have been 
reported in the urine of RTRs with ADV infection ${ }^{(51,52)}$. Storsley et al. in 2011 found that four patients demonstrated decoy cells in their urine over the course of a few months, during which time the urine culture and PCR was positive for ADV while BKV virus was negative (53). Surveillance studies of asymptomatic adult RTRs have shown an incidence of adenoviral viremia by PCR testing of $6.5 \%$ and viruria by $11 \%{ }^{(5,54)}$. Asymptomatic viral shedding in the urine makes urinary cultures unreliable in the absence of signs and symptoms of disease activity. The presence of white cell casts with decoy cells on urinalysis may increase the suspicion for ADV infection (54).

In our transplantation center in Baghdad, there is no protocol biopsy for RTRs, and this makes the exact diagnosis of renal pathology extremely difficult. The presence of high adenoviral load in plasma, with high decoy cells shedding, and the significant association of viremia with lymphopenia (both qualitatively and quantitatively) ( $p=0.007$, and 0.023) respectively, all these give strong association between this virus and the patients' clinical manifestations. However, other infections should be excluded.

In conclusion, ADV infection is an important cause of many diseases in RTRs, which is evident by high frequency of this virus with high viral load in these RTRs.

\section{Acknowledgments}

Authors would like to acknowledge all the staff members in the Center of Kidney Diseases and Transplantation, Medical City of Baghdad, for their cooperation in accomplishing this study.

\section{Authors' contribution}

Ahmed: Collection of specimens, DNA extraction, and real time-PCR, writing of the references. Dr. Hussein: Consultant Nephrologist help in providing all patients' data and in selection of patients. Dr. Al-Obaidi: Supervision and performance of viral DNA extraction and real time-PCR run, writing of the manuscript. Dr. Kadhim: Final editing of the manuscript. Dr. Ghazi: Statistical analysis.
Conflict of interest

Authors declare no conflict of interest.

\section{Funding}

There is no funding source for this research.

\section{References}

1. Huang $G, X u$ W. [Recent advance in new types of human adenovirus]. Bing Du Xue Bao. 2013; 29(3): 342-8.

2. Buckwalter SP, Teo R, Espy MJ, et al. Real-time qualitative PCR for 57 human adenovirus types from multiple specimen sources. J Clin Microbiol. 2012; 50(3): 766-71. doi: 10.1128/JCM.05629-11.

3. Echavarría M. Adenoviruses in immunocompromised hosts. Clin Microbiol Rev. 2008; 21(4): 704-15. doi: 10.1128/CMR.00052-07.

4. Singh G, Robinson CM, Dehghan S, et al. Homologous recombination in E3 genes of human adenovirus species D. J Virol. 2013; 87(22): 12481-8. doi: 10.1128/JVI.01927-13.

5. Ison MG. Adenovirus infections in transplant recipients. Clin Infect Dis. 2006; 43(3): 331-9. doi: 10.1086/505498.

6. Humar A, Kumar D, Mazzulli T, et al. A surveillance study of adenovirus infection in adult solid organ transplant recipients. Am J Transplant. 2005; 5(10): 2555-9. doi: 10.1111/j.1600-6143.2005.01033.x.

7. Robinson CM, Singh G, Lee JY, et al. Molecular evolution of human adenoviruses. Sci Rep. 2013; 3(1): 1812. doi: 10.1038/srep01812.

8. Schechter-Finkelstein $T$, Gassas A, Weitzman $S$, et al. Hematopoietic stem-cell transplantation following solid-organ transplantation in children. Bone Marrow Transplant. 2011; 46(10): 1321-5. doi: 10.1038/bmt.2011.153.

9. Institut national d'excellenceen santé eten services sociaux (INESSS). Quantitative Real-Time PCR for Detection of Adenovirus in Immunosuppressed Patients 2013.

10. Lion T. Adenovirus infections in immunocompetent and immunocompromised patients. Clin Microbiol Rev. 2014; 27(3): 441-62. doi: 10.1128/CMR.0011613.

11. Watcharananan SP, Avery $R$, Ingsathit $A$, et al. Adenovirus disease after kidney transplantation: Course of infection and outcome in relation to blood viral load and immune recovery. Am J Transplant. 2011; 11(6): 1308-14. doi: 10.1111/j.16006143.2011.03479.x.

12. Kapila K, Nampoory MRN, Johny K V, et al. Role of urinary cytology in detecting human polyoma $B K$ virus in kidney transplant recipients: A preliminary report. Med Princ Pract. 2007;16(3): 237-9. doi: 10.1159/ 000100398.

13. Asim M, Chong-Lopez A, Nickeleit V. Adenovirus infection of a renal allograft. Am J Kidney Dis. 2003; 41(3): 696-701. doi: 10.1053/ajkd.2003.50133. 
14. Boldorini R, Brustia M, Veggiani $C$, et al. Periodic assessment of urine and serum by cytology and molecular biology as a diagnostic tool for BK virus nephropathy in renal transplant patients. Acta Cytol. 2005; 49(3): 235-43. doi: 10.1159/000326143.

15. Greber UF, Arnberg N, Wadell G, et al. Adenoviruses from pathogens to therapeutics: A report on the $10^{\text {th }}$ International Adenovirus Meeting. Cell Microbiol. 2013; 15(1): 16-23. doi: 10.1111/cmi.12031.

16. Al-Obaidi AB, Abd KH, Kadhim $H S$, et al. BK polyomavirus and cytomegalovirus co-infections in renal transplant recipients: a single center study. Int J Adv Res. 2015; 3(1): 856-64.

17. Al-Obaidi $A B, A b d K H$, Habib MA, et al. Detection of $B K$ polyomavirus using real time $P C R$ in 99 renal transplant recipients. JIARM 2015; 3(1): 131-41.

18. Al-Obaidi AB, Qasim BJ, Husain $A G$, et al. $B K$ polyomavirus-infected decoy cells in urine cytology specimens of renal transplant recipients. Iraqi J Med Sci. 2015; 13(1): 70-5.

19. Jasim MB, Al-Saedi AJH, Hussein MR, et al. High prevalence of John Cunningham viruria in renal transplant recipients. Iraqi J Med Sci. 2017; 15(2): 108-15. doi: 10.22578/IJMS.15.2.2.

20. Shams-aldein SA, Abdlameer AS, Al-Obaidi AB, et al. Detection of Epstein Barr virus in renal transplant recipients: two centers study. accepted for publication. Iraqi J Med Sci. 2015; 13(2): 191-9.

21. Jasim HR. A study of viral load of HHV-6 DNA in samples of Iraqi patients during the first year after kidney transplantation. MSc thesis, Microbiology Department, College of Medicine, Al-Nahrain University, Iraq. 2015.

22. Hlail ZA, Abdulamir AS, AJH. The seropositivity of Parvovirus B19 among kidney transplant recipients. Iraqi JMS. 2017; 15(1): 88-93. doi: 10.22578/IJMS.15.1.11.

23. Suparno C, Milligan DW, Moss PA et al. Adenovirus infections in stem cell transplant recipients: recent developments in understanding of pathogenesis, diagnosis and management. Leuk Lymphoma. 2004; 45(5): 873-85. doi: 10.1080/ 10428190310001628176.

24. Kampmann B, Cubitt D, Walls $T$, et al. Improved outcome for children with disseminated adenoviral infection following allogeneic stem cell transplantation. Br J Haematol. 2005; 130(4): 595603. doi: 10.1111/j.1365-2141.2005.05649.x.

25. Rubin RH, Kemmerly SA, Conti D, et al. Prevention of primary cytomegalovirus disease in organ transplant recipients with oral ganciclovir or oral acyclovir prophylaxis. Transpl Infect Dis. 2000; 2(3): 112-7.

26. Kojaoghlanian T, Flomenberg P, Horwitz MS. The impact of adenovirus infection on the immunocompromised host. Rev Med Virol. 2003; 13(3): 155-71. doi: 10.1002/rmv.386.

27. Erard V, Huang M-L, Ferrenberg J, et al. Quantitative real-time polymerase chain reaction for detection of adenovirus after $\mathrm{T}$ cell-replete hematopoietic cell transplantation: viral load as a marker for invasive disease. Clin Infect Dis. 2007; 45(8): 958-65. doi: $10.1086 / 521851$.

28. Claas ECJ, Schilham MW, De Brouwer CS, et al. Internally controlled real-time PCR monitoring of adenovirus DNA load in serum or plasma of transplant recipients. J Clin Microbiol. 2005; 43(4): 1738-44. doi: 10.1128/JCM.43.4.1738-1744.2005.

29. Schilham MW, Claas EC, van Zaane W, et al. High levels of adenovirus DNA in serum correlate with fatal outcome of adenovirus infection in children after allogeneic stem-cell transplantation. Clin Infect Dis. 2002; 35(5): 526-32. doi: 10.1086 /341770.

30. Schneider-Brachert W, Tchikov V, Merkel O, et al. Inhibition of TNF receptor 1 internalization by adenovirus $14.7 \mathrm{~K}$ as a novel immune escape mechanism. J Clin Invest. 2006; 116(11): 2901-13. doi: $10.1172 / \mathrm{JCl} 23771$.

31. Lichtenstein DL, Toth K, Doronin K, et al. Functions and mechanisms of action of the adenovirus E3 proteins. Int Rev Immunol. 2004; 23(1-2): 75-111. doi: 10.1080/08830180490265556.

32. Hansen TH, Bouvier M. MHC class I antigen presentation: learning from viral evasion strategies. Nat Rev Immunol. 2009;9(7): 503-13. doi: $10.1038 /$ nri2575.

33. Parasuraman $R$, Zhang PL, Samarapungavan $D$, et al. Severe necrotizing adenovirus tubulointerstitial nephritis in a kidney transplant recipient. Case Rep Transplant. 2013; 2013: 969186. doi: 10.1155/2013/969186.

34. Kolankiewicz LM, Pullman J, Raffeld $M$, et al. Adenovirus nephritis and obstructive uropathy in a renal transplant recipient: Case report and literature review. NDT Plus. 2010; 3(4): 388-92. doi: $10.1093 /$ ndtplus/sfq024.

35. Ramírez J, Bostock IC, Martin-Onraët A, et al. Fever, haematuria, and acute graft dysfunction in renal transplant recipients secondary to adenovirus infection: two case reports. Case Reports Nephrol. 2013; 2013: 1-6. doi: 10.1155/2013/195753.

36. Klein J, Kuperman M, Haley $C$, et al. Late presentation of adenovirus-induced hemorrhagic cystitis and ureteral obstruction in a kidney-pancreas transplant recipient. Proc (BaylUniv Med Cent). 2015; 28(4): 488-91.

37. Watanabe A, Carraro E, Camargo C, et al. Human adenovirus detection among immunocompetent and immunocompromised patients presenting acute respiratory infection. Rev Soc Bras Med Trop. 2013; 46(2): 161-5. doi: 10.1590/0037-8682-1699-2013.

38. Noel N, Rammaert B, Zuber J, et al. Lower respiratory tract infection in a renal transplant recipient: do not forget Metapneumovirus. Case Rep Transplant. 2012; 2012: 353871. doi: 10.1155/2012/353871.

39. Richards A, Chuen JN, Taylor C, et al. Acute respiratory infection in a renal transplant recipient. Nephrol Dial Transplant. 2012; 20(12): 2848-50. doi: 10.1093/ndt/gfi167.

40. Florescu DF, Islam MK, Mercer DF, et al. Adenovirus infections in pediatric small bowel transplant 
recipients. Transplant J. 2010; 90(2): 198-204. doi: 10.1097/TP.0b013e3181e0de97.

41. Pinchoff RJ, Kaufman SS, Magid MS, et al. Adenovirus infection in pediatric small bowel transplantation recipients. Transplantation. 2003; 76(1): 183-9. doi: 10.1097/01.TP.0000072808.93060.0F.

42. Kosulin K, Geiger E, Vécsei A, et al. Persistence and reactivation of human adenoviruses in the gastrointestinal tract. Clin Microbiol Infect. 2016; 22(4): 381.e1-381.e8. doi: 10.1016/j.cmi.2015.12.013.

43. Hofland CA, Eron LJ, Washecka RM. Hemorrhagic adenovirus cystitis after renal transplantation. Transplant Proc. 2004; 36(10): 3025-7. doi: 10.1016/j.transproceed.2004.10.090.

44. Rady K, Walters G, Brown M, et al. Allograft adenovirus nephritis. Clin Kidney J. 2014; 7(3): 28992. doi: $10.1093 / \mathrm{ckj} / \mathrm{sfu020}$.

45. Walls T, Shankar AG, Shingadia D. Adenovirus: An increasingly important pathogen in paediatric bone marrow transplant patients. Lancet Infect Dis. 2003; 3(2): 79-86. doi: 10.1016/S1473-3099(03)00515-2.

46. Heemskerk B, Lankester ACC, van Vreeswijk T, et al. Immune reconstitution and clearance of human adenovirus viremia in pediatric stem-cell recipients. J Infect Dis. 2005; 191(4): 520-30. doi: 10.1086/427513.

47. Kim HT, Armand P, Frederick D, et al. Absolute lymphocyte count recovery after allogeneic hematopoietic stem cell transplantation predicts clinical outcome. Biol Blood Marrow Transplant. 2015; 21(5): 873-80. doi: 10.1016/j.bbmt.2015.01.019.

48. Barraclough K, Oliver K, Playford EG, et al. Lifethreatening adenovirus infection in a kidney transplant recipient. NDT Plus. 2009; 2(3): 250-3. doi: 10.1093/ndtplus/sfp003.
49. Nanmoku K, Ishikawa N, Kurosawa A, et al. Clinical characteristics and outcomes of adenovirus infection of the urinary tract after renal transplantation. Transpl Infect Dis. 2016; 18(2): 234-9. doi: 10.1111/tid.12519.

50. Randhawa P, Mannon RB. A case of late kidney allograft failure: A clinical pathological conference from american society of nephrology kidney week 2011. Clin J Am Soc Nephrol. 2012; 7(11): 1884-9. doi:10.2215/CJN.04920512.

51. Maia TMC, Silva SFR, Silva SL, et al. Polyomavirusinfected decoy cells in cytocentrifuged urine cytology specimens from renal transplant recipients. Acta Cytol. 2011; 55(5): 445-8. doi: 10.1159/000329625.

52. Chakera A, Dyar O-J, Hughes $E$, et al. Detection of polyomavirus BK reactivation after renal transplantation using an intensive decoy cell surveillance program is cost-effective. Transplantation. 2011; 92(9): 1018-23. doi: 10.1097/TP. 0b013e318230c09b.

53. Storsley L, Gibson IW. Adenovirus interstitial nephritis and rejection in an allograft. J Am Soc Nephrol. 2011; 22: 1423-7. doi: 10.1681/ASN.2010090941.

54. Ison $M G$, Green $M$, son $M G 1$, Green $M$; AST Infectious Diseases Community of Practice. Adenovirus in solid organ transplant recipients. Am J Transplant. 2009; 9(SUPPL. 4): S161-5. doi: 10.1111/j.1600-6143.2009.02907.x.
Correspondence to Asmaa B. Al-Obaidi E-mail: hindmajed91@gmail.com dr.asmaa.baqir@colmed-alnahrain.edu.iq Received Oct. 17 2017 Accepted Dec. 19 2017 